ks. Andrzej Proniewski

Uniwersytet w Biatymstoku

\title{
Wiara jako postawa człowieka myślącego w refleksji Benedykta XVI
}

\section{FAITH AS A DISPOSITION OF MAN IN BENEDICT XVI'S REFLECTION}

Man, as a thinking being, and is a believer by nature. The faith in God in Three Persons has got both an individual and social dimension. It is conveyed to an individual within the community of the Church. Those who believe meet God, and the initiative comes from Him. Owing to the grace received through the baptism, man is initiated into the life in faith. To believe means to follow the way that makes of human life meaningful. The aim of the article is to present, from a panoramic perspective, Benedict XVI's deep reflection on faith.

Key words: faith , Benedict XVI, God's grace, Church.

\section{Wstęp}

Jednym z fundamentalnych zagadnień tworzących fenomen życia jest wiara. To właśnie ona ,,jest poręką tych dóbr, których się spodziewamy, dowodem tych rzeczywistości, których nie widzimy" (Hbr 11, 1). Przyczynia się do spełnienia egzystencjalnego, prowadzi ku Bogu i zapewnia perspektywę eschatologicznego bytowania. Nie sposób mówić o życiu, nie mówiąc o wierze. Rozumienie wiary wymaga pokory myślenia i akceptacji celu, który nie jest zdeterminowany czasem i przestrzenią, a także przyjęciem jakichś prawd ideowo-światopoglądowych, ale złożonym procesem, który prowadzi do Boga. 
„Centralną tajemnicą wiary i życia chrześcijańskiego jest tajemnica Trójcy Świętej”" Wiara w jednego Boga w trzech Osobach jest jednym z najbardziej wymagających prerogatyw chrześcijaństwa. Sam proces wiary inicjuje łaska Boża dana przy chrzcie, który umożliwia spotkanie z Bogiem. Inicjatywa zawsze leży po stronie Boga, który pierwszy wychodzi człowiekowi naprzeciw, wzywa go i zaprasza, domagając się współpracy. Odpowiedzią na to wezwanie jest wiara człowieka. Wiara ma zasadnicze znaczenie w życiu każdego człowieka i ciągle wywiera ogromny wpływ na niego i kulturę, w której on żyje. Sprawia, że wielu ludzi postępuje według określonych i pewnych zasad. Udziela wskazówek do lepszego życia, wyznacza ścieżki ludzkiego postępowania, wskazuje drogę zagubionym i potrzebującym pomocy. Bez niej człowiek czuje się zdezorientowany i pozbawiony sensu istnienia. Wiara jest siłą, która umacnia człowieka do doskonalenia życia. Dlatego warto wierzyć, a przez to stawać się lepszym, upodabniając się do Tego, w Kogo się wierzy.

Benedykt XVI nauczał: „chrześcijaninem nie zaczyna się być poprzez podjęcie decyzji etycznej czy poprzez wielką ideę, ale tylko poprzez spotkanie z Osobą, która wskazuje nam nowe życiowe horyzonty a co za tym idzie decydujący kierunek życia”" zaś: „chrześcijaństwo to nie system intelektualny, zbiór dogmatów czy moralizm. Chrześcijaństwo to spotkanie, historia miłosna, to wydarzenie"3.

Wiara i rozum wzajemnie się wspomagają, ponieważ dzięki rozumowi wiara staje się bardziej pogłębiona i lepiej uzasadniona, a wydarzenie spotkania nabiera nie tyle charakteru emocjonalnego, co bardziej racjonalnego. Dialog wiary i rozumu prowadzony szczerze i konsekwentnie pozwala dostrzec racjonalność procesu wiary w Boga ${ }^{4}$. Człowiek współpracujący z łaską wchodzi w indywidualną relację z Chrystusem, którego obdarza autorytetem. Takie nastawienie sprawia, że człowiek wierzący nabiera pewności w życiu i poznaniu albowiem bazuje na potrzebie odkrycia ostatecznej prawdy egzystencjalnej, która zawiera się w Bogu. Ten osobisty kontakt interpersonalny przejawia się w pokornym odniesieniu osób względem siebie z możliwością głębszego zawierzenia prowadzącego do naśladowania Boga objawionego w Jezusie Chrystusie.

\section{KKKK 44.}

2 Benedykt XVI, Deus Caritas Est, Kraków, 2006, s. 3.

3 T. Rowland, Wiara Ratzingera. Teologia Benedykta XVI, Kraków 2010, s.115.

4 Benedykt XVI, Radość ptynaca $z$ wiary $i$ wychowanie nowych pokolen. Do uczestników kongresu diecezji Rzymu, „L'Oss Rom”(PL), 12(2006), s.15. 
Naturalnym środowiskiem rozwoju wiary jest Kościół. W Kościele człowiek dojrzewa i doskonali siebie nierozdzielnie łącząc postawę wiary z nadzieją i miłością. Te cnoty teologalne wzajemnie się warunkują, umacniają, dopełniają i na siebie oddziałują. W proces wiary wpisane są również doświadczenia życiowe, które pomagają wzrastać w wierze.

Pytanie o ostateczną przyszłość, jaka czeka każdego człowieka, nadaje pełny sens istnieniu, ponieważ ukierunkowuje program życia nie tylko ku horyzontom ograniczonym i przejściowym, ale bardziej ku poszerzeniu wizji życia o istnienie eschatologiczne, nieprzemijające, które uzupełnia rzeczywistość ziemską o wieczną. Bóg przygotował trwałą perspektywę, dlatego jako ludzie: „Pożądamy razem ojczyzny niebieskiej, tęsknimy za ojczyzną niebieską, czujemy się pielgrzymami na tym świecie"

\section{Wiara w Boga Trójjedynego}

„Centralną tajemnicą wiary i życia chrześcijańskiego jest tajemnica Trójcy Świętej. Chrześcijanie są chrzczeni w imię Ojca i Syna i Ducha Świętego". Wiara w jednego Boga w trzech Osobach jest jednym z najbardziej specyficznych elementów chrześcijaństwa. Żadna inna religia tej tajemnicy nie podaje do wierzenia. Istnienie Boga Trójjedynego jest dogmatem wiary. Nie wyznajemy trzech bogów, ale jednego Boga w trzech Osobach: „Trójcę współistotną”. Osoby Boskie nie dzielą między siebie jedynej Boskości, ale każda z nich jest całym Bogiem: „Ojciec jest tym samym, co Syn, Syn tym samym, co Ojciec, Duch Święty tym samym, co Ojciec i Syn, to znaczy jednym Bogiem, co do natury”. „Każda z trzech Osób jest tą rzeczywistością, to znaczy substancją, istotą lub naturą Bożą"7. W historii Zbawienia wszystkie osoby Trójcy Świętej odgrywają istotną rolę: Bóg Ojciec stworzył świat i człowieka, Syn Boży odkupił człowieka, Duch Święty prowadzi do uświęcenia.

Papież Benedykt XVI w swoich przemówieniach pouczał o Trójcy Przenajświętszej podkreślając, że człowiek pozwalając prowadzić się Duchowi Świętemu może upodobnić się do Chrystusa i głębiej zanurzyć się w życie, Trójjedynego Boga. Podkreślał, że Trójca stanowi centrum chrześcijańskiej wiary i życia ${ }^{8}$.

\footnotetext{
$5 \quad$ Św. Augustyn, Komentarz do Ewangelii św. Jana, Homilia 35,9.

$6 \quad$ KKKK 44.

$7 \quad$ KKK 253.

8 Benedykt XVI, Otwierajcie serca na dary Ducha Świętego. Czuwanie młodzieży na hipodromie w Randwick, „L'Oss Rom” (PL), 9(2008), s. 26.
} 
Człowiekowi wierzącemu łatwiej jest nawiązać relację z osobą Jezusa Chrystusa - Boga Człowieka aniżeli z osobą Ducha Świętego. Duch Święty był niejednokrotnie pomijany w nauczaniu. Duch Święty, Duch miłości Ojca i Syna - to źródło życia, które uświęca, ponieważ „miłość Boża rozlana jest w sercach naszych przez Ducha Świętego, który został nam dany" (Rz 5, 5). Nie wystarczy Go poznać, trzeba Go przyjąć jako przewodnika ludzkich dusz, jako „wewnętrznego Nauczyciela”, który wprowadza w tajemnicę trynitarną i tylko On może otworzyć człowieka na wiarę i pozwolić żyć nią w pełni każdego dnia9 .

Duch Święty jest najdoskonalszym darem Boga dla człowieka, a więc najwyższym świadectwem Jego miłości wyrażającej w owej miłości „tak dla życia”. To „tak dla życia” zyskuje swoją pełnię w Jezusie z Nazaretu i w jego zwycięstwie nad złem dokonanym przez Odkupienie ${ }^{10}$. Bo tylko Chrystus może zaspokoić najgłębsze pragnienia ludzkiego serca; tylko On może uczłowieczyć ludzkość i doprowadzić do jej „przebóstwienia”. Mocą swojego Ducha napełnia Bożą miłością, która sprawia, że osoba ludzka zdolna jest miłować bliźniego i gotowa mu służyć. Duch Święty daje światło, objawia Chrystusa ukrzyżowanego i zmartwychwstałego, wskazuje drogę, by stać się podobnym do Niego, czyli być narzędziem i wyrazem miłości, która od Niego emanuje. ${ }^{11}$

Duch Święty jest więzią jedności wewnątrz Trójcy Przenajświętszej: jedności jako komunii, jedności jako zamieszkującej miłości i jedności jako tej, która obdarowuje i sama jest darem. ${ }^{12}$

Słowo „Duch” i „Święty” odnoszą się do tego, co Boskie w Bogu, innymi słowy do tego, co jest wspólne Ojcu i Synowi - do ich komunii. Jeżeli zatem cechą wyróżniającą Ducha Świętego jest bycie tym, co współdzielą ze sobą Ojciec i Syn, to właściwością Ducha jest jedność. Jest to jedność przeżywanej komunii, jedność Osób pozostających ze sobą w stałej relacji wzajemnego obdarowywania się. Ojciec i Syn obdarowują się nawzajem. Duch Święty sprawia, że człowiek może mieszkać w Bogu, a Bóg w człowieku. Tego właśnie dokonuje miłość. Bóg jako miłość udziela się w Duchu Świętym. On daje światu - miłość rozwiewającą niepewność, miłość pokonującą lęk przed zdradą,

$9 \quad$ Benedykt XVI, Duch Świętyzstapi nawas, otrzymacie Jego moc ibędziecie moimi świadkami (Dz 1,8). Orędzie na XXIII Światowy Dzień Młodzieży, „L'Oss Rom” (PL), 9(2007), s. 27.

10 Tamże, s. 26.

11 Tamże.

12 Benedykt XVI, Otwierajcie serca na dary Ducha Świętego. Czuwanie mtodzieży na hipodromie w Randwick, „L'Oss Rom” (PL), 9(2008), s. 27. 
miłość niosącą w sobie wieczność, prawdziwą miłość, która wprowadza w trwałą jedność.

Duch Święty jest „darem Bożym”, źródłem wewnętrznym, które zaspokaja najgłębsze pragnienia. Jest sprawcą jedności ludzi wierzących w Jezusa Chrystusa. Wierny swej naturze dawcy i daru działa poprzez Wiara każdego człowieka. I dlatego miarą dla ludzi ma być - jednocząca miłość, wyzwaniem - trwała miłość, misją - miłość dająca siebie ${ }^{13}$.

\section{Wiara jako łaska}

„Wiara jest darem, danym przy chrzcie, który umożliwia nam spotkanie z Bogiem"14. Wiarę zapoczątkowuje w człowieku łaska Boża i nie może być ona dziełem człowieka. Jest jakby otworzeniem okna na Boga, ale to okno może otworzyć tylko Bóg. Nie można otworzyć się na Boga bez Boga. Bóg otwierając człowieka na siebie samego, okazuje mu swoją darmową miłość, czyli łaskę ${ }^{15}$. Już synod w Orange w 529 roku głosił, że wiara jest darem Bożym ${ }^{16}$. Nawet samo jej pragnienie i zapoczątkowanie jest już owocem działającej w człowieku łaski. Wiara jest tajemnicą zachodzącą między człowiekiem a Bogiem. Jest całkowicie wolnym aktem osoby, a jednocześnie jednostka przeżywa ją jako ogarnięcie jej przez Boga, jako wezwanie nie do odparcia, jako dar ${ }^{17}$ : „nikt nie może przyjść do Mnie, jeżeli nie zostało mu to dane przez Ojca"(J 6,65). Dlatego też nie odmawia Opatrzność Boża koniecznej do Zbawienia pomocy takim, którzy bez własnej winy w ogóle nie doszli jeszcze do wyraźnego poznania Boga, a usiłują nie bez łaski Bożej, wieść uczciwe życie. Cokolwiek bowiem znajduje się w nich z dobra i prawdy, Kościół traktuje jako przygotowanie do Ewangelii i jako dane im przez Tego, który każdego człowieka oświeca, aby ostatecznie

\section{Tamże.}

Benedykt XVI, Przemówienie Ojca Świętego, (Jasna Góra), [w:] Trwajcie mocni $w$ wierze. Benedykt XVI w Polsce, Kraków 2006, s. 54.

B. Ferdek, Nasza Siostra - Córa i Matka Pana. Mariologia, jako przestrzeń syntezy dogmatyki, Świdnica 2007, s.20.

„Jeśli ktoś twierdzi, że jak wzrost, tak i początek wiary i sama chęć wierzeniadzięki której wierzymy w Tego, co usprawiedliwia grzesznika i dochodzimy do odrodzenia przez chrzest św. - dzieje się nie z daru łaski, tj. przez natchnienie Ducha Świętego naprowadzającego wolę naszą od niewiary do wiary, od złego życia do pobożności, lecz mamy to w sposób naturalny, ten sprzeciwia się apostolskiej nauce.” II Synod w Orange, Kanon 5, [w:] S. Głowa, I. Bieda (red.), Breviarium fidei, Poznań 2000, s. 298.

A. Zuberbier (red.), Stownik Teologiczny, Katowice 1998, s. 633. 
posiadł życie ${ }^{18}$. Wiara nie jest więc wynikiem naturalnego działania człowieka, lecz przychodzącym z zewnątrz podarunkiem, którym może zostać obdarowany każdy człowiek.

Bóg pierwszy ukochał człowieka, którego stworzył, dlatego inicjatywa zawsze leży po Jego stronie. Do Boga zawsze należy pierwszy krok. On pierwszy wychodzi naprzeciw człowiekowi. On sam daje się poznać, objawia się, wzywa, zaprasza. Wiara człowieka jest zawsze odpowiedzią na Boże wezwanie. Działanie Boga - jego łaski polega także i na tym, że od wewnątrz pobudza człowieka, uzdalnia, otwiera mu oczy na przyjęcie prawdy objawionej. „Łaską bowiem, jesteśmy zbawieni przez wiarę, a to nie pochodzi od nas, lecz jest darem Boga" (Ef 2, 8).

W sakramencie chrztu człowiek otrzymuje wraz z życiem nadprzyrodzonym dar wiary. W ochrzczonym poprzez wszczepienie w Chrystusa dokonuje się podstawowa konsekracja - poświęcenie osoby ludzkiej Bogu i powołanie jej do świętości. Chrzest jest więc wejściem na chrześcijańską drogę, wstępem do życia w Kościele ${ }^{19}$. Przez chrzest Jezus powołuje każdego, aby Go naśladować w konkretnych uczynkach, miłować Go ponad wszystko i służyć $\mathrm{Mu}$ w braciach ${ }^{20}$. Ten pierwszy sakrament Kościoła jest zainicjowaniem naszego „ukrycia z Chrystusem w Bogu". Chrzest jest źródłem wiary. On rozpoczyna w nas życie nadprzyrodzone, które jest życiem wiary, nadziei i miłości ${ }^{21}$. Stąd wynika, że wyznanie wiary nie jest sumą zdań, nie jest jakąś tylko teorią. W tajemnicy chrztu Bóg pochyla się nad ludźmi, wychodzi naprzeciw i sprawia, że jedni zbliżają się do drugich. Chrzest jest znakiem włączenia do Bożej rodziny, która tworzy jedną wielką powszechną wspólnotę Kościoła ${ }^{22}$.

\section{Wiara jako osobista relacja z Chrystusem}

Chrześcijańskie rozumienie wiary w jej najgłębszej istocie i podstawowych strukturach jest od wieków niezmienne. Nauczanie Kościoła definiuje ją w następujący sposób: „Wiara jest najpierw osobowym

$18 \quad$ KK 16.

19 Benedykt XVI, Życie jest poszukiwaniem prawdy, dobra i piękna. Spotkanie z mtodzieża na nabrzeżu Barangaroo, „L'Oss Rom” (PL), 9(2008), s. 15.

Benedykt XVI, Orędzie na XXV Światowy Dzień Mtodzieży, „L'Oss Rom”(PL), $5(2010)$, s. 5.

T. Dajczer, Rozważania o wierze. Z zagadnień teologii duchowości, Częstochowa 1992, s.166. 
przylgnięciem człowieka do Boga; równocześnie i w sposób nierozdzielny jest ona dobrowolnym uznaniem całej prawdy, którą Bóg objawił"23. Stąd wynika, że ,wiara chrześcijańska z samej swej istoty ma strukturę personalną. Jest ona odpowiedzią osoby na osobiste wezwanie" ${ }^{24}$. Jest „osobistą relacją z Jezusem Chrystusem, spotkaniem z Synem Bożym"25. A zatem kluczowe sformułowanie wiary nie brzmi „wierzę w coś”, ale „wierzę w Ciebie”. ${ }^{26}$ Jednak znajomość tego „wierzę w coś” jest konieczna dla samej wiary i w konsekwencji musi przechodzić w „wierzę w Ciebie”. Nie można bowiem wierzyć w coś, czego się nie zna. Wiara i poznanie, i uzyskane dzięki temu rozumienie rzeczywistości są więc nierozłącznie ze sobą związane.

Wiara nie jest ideologią, która poświęca osobę jakiejś idei. W centrum chrześcijaństwa nie stoi jakaś idea, ale Osoba Jezusa Chrystusa. Wiara jest osobistą więzią między Nim a wierzącym w Niego. Wprowadza w komunię z Nim, a komunia jest możliwa między osobami. Bóg jest komunią trzech Osób: Ojca, Syna i Ducha Świętego i wprowadza w tę komunię człowieka ${ }^{27}$.

W akcie wiary człowiek przyjmuje dar Boga, którym jest On sam, który objawia się. Konkretnym wymiarem wiary jest zawierzenie Jezusowi Chrystusowi i Ojcu, który Go posłał. Nawiązanie bardzo osobistej relacji z Stwórcą i Odkupicielem, za sprawą Ducha Świętego, który działa w sercach i na tej więzi budowanie całego życia. Chrystus jest całą Prawdą, która stała się Człowiekiem i przyciąga do siebie cały świat ${ }^{28}$.

Każdy człowiek ma osobisty i niepowtarzalny sposób przeżywania wiary i Bożych prawd ${ }^{29}$, dlatego każde nowe pokolenie musi na swój sposób odkrywać piękno i radość wiary, ponieważ wiara angażuje to, co każdy ma najbardziej własnego, najbardziej intymnego: serce, intelekt, wolność w głęboko osobistą relację z Panem, który działa w ludzkim

KKK 150.

A. Proniewski, Doświadczenie wiary $w$ życiu młodego człowieka w nauczaniu Benedykta XVI, „Rocznik Teologii Katolickiej” IX, Białystok 2010, s. 99.

Benedykt XVI, Orędzie na XXVI Światowy Dzień Młodzieży, „L'Oss Rom” (PL), 10(2010), s. 6 .

J. Ratzinger, Wprowadzenie w chrześcijaństwo, Kraków 2007, s. 77.

B. Ferdek, Nasza Siostra..., dz. cyt., s. 23.

Benedykt XVI, Radość płynaca z wiary $i$ wychowanie nowych pokoleń. Do uczestników kongresu diecezji Rzymu, „L’Oss Rom” (PL), 12(2006), s. 15.

A. Proniewski, Doświadczenie wiary w życiu..., dz. cyt., s. 99. 
wnętrzu ${ }^{30}$. On objawia tożsamość każdego, a w przyjaźni z Nim życie rozwija się i w pełni realizuje ${ }^{31}$.

Pełna dojrzałość osoby, jej wewnętrzna stabilność mają swoje fundamenty właśnie w relacji z Bogiem, relacji, która przychodzi przez spotkanie z Jezusem Chrystusem. Więź oparta na głębokim zaufaniu, autentycznej przyjaźni z Jezusem jest w stanie przynieść młodemu człowiekowi to, czego mu najbardziej potrzeba, by właściwie podejść do życia: pogodę i światło wewnętrzne, nawyk pozytywnego myślenia, wielkoduszność wobec innych, gotowość do płacenia osobiście za dobro, sprawiedliwość i prawdę. Bez relacji z Bogiem trudno jest mówić o pełni życia, ponieważ „życie w swojej pełni jest relacją z Tym, który jest źródłem życia. Jeśli pozostajemy w relacji z Tym, który nie umiera, który sam jest Życiem i Miłością, wówczas mamy życie"32.

Wiara chrześcijańska to spotkanie z żywą Osobą, która daje życiu nowe horyzonty i w ten sposób decydujący kierunek. I kiedy serce człowieka otwiera się na Boski plan, rozpoznanie jego głosu i podążanie za nim nie kosztuje go wiele, a może okazać się decydujące dla życia ${ }^{33}$.

\section{Wiara jako zaufanie i naśladowanie Chrystusa}

Osobista relacja człowieka z Jezusem Chrystusem przejawia się w zaufaniu. Wiara jawi się, jako zaufanie osobie - nie zwyczajnej osobie, ale Chrystusowi. Wiara jest więc ufnością Bogu, powierzeniem się na dobre i na złe Temu, dla którego „nie ma nic niemożliwego” (Łk 1,37). Ta ufność jest jakby zabezpieczeniem się u Boga, który z największego zła może wyprowadzić dobro.

„Amen” w języku hebrajskim ma ten sam źródłosłów, co wyraz „wierzyć” i oznacza: „stanąć z pełnym zaufaniem na określonym gruncie nie dlatego, że ja tę podstawę stworzyłem i sprawdziłem, ale właśnie dlatego, że jej nie stworzyłem i nie mogę jej sprawdzić" 34 . Wiara, będąca głębokim zaufaniem Bogu, wprowadza wierzącego w nowy świat, którego obrazem może być Piotr kroczący po wodzie (Mt 14, 22-33). Wierzący, ufając Chrystusowi, dla którego nie ma nic niemożliwego, może z Nim kroczyć po wzburzonym morzu. Bez za-

\footnotetext{
30 Benedykt XVI, Radość ptynaca z wiary..., „L'Oss Rom” (PL), 12(2006), s.13.

Benedykt XVI, Orędzie na XXVI Światowy Dzień Mtodzieży, „L'Oss Rom”(PL), 10(2010), s.6.

Benedykt XVI, Spe Salvi o nadziei chrześcijańskiej, Poznań 2007, s.37.

Benedykt XVI, Orędzie na XXVIŚwiatowy Dzień Młodzieży, „L'Oss Rom” (PL), 10(2010), s.4. 
ufania wiara staje się „małą wiarą” (Mt 14,31) ${ }^{35}$. Nie wystarczy samo stwierdzenie „wierzę", trzeba bezgranicznie zaufać Jezusowi i zaprosić go do swojego życia. On ma być jego Panem. Zaufać Chrystusowi to nic innego jak uczynić całkowity dar ze swego życia, bez względu na ludzkie koszty i korzyści, ale z bezgraniczną ufnością w Boga ${ }^{36}$. Gdy wierzący będzie słuchać Jezusa, iść za Nim, wtedy stanie się naprawdę sobą. Nie jest ważne realizowanie własnych pragnień, tylko spełnianie Jego woli. Czyniąc tak, życie staje się prawdziwe. Przez wiarę można budować na Chrystusie (Kol 2,7 ${ }^{37}$. Budować na Chrystusie oznacza konkretnie odpowiedzieć na wezwanie Boga, zaufać Mu i żyć według Jego słowa ${ }^{38}$. Wiara jest więc sprawą zaufania Temu, który jest drogą, prawdą i życiem.

Wyrażenie „pójście za Chrystusem” opisuje ogólnie całe życie chrześcijańskie. Pójście za Chrystusem na początku oznaczało porzucenie swoich zajęć, swoich spraw, całego swojego życia. Oznaczało wybrać nowy zawód - zawód ucznia, który polegał na chodzeniu za swoim Mistrzem w pełnym zawierzeniu jego przewodnictwu. To „pójście za” miało wymiar zewnętrzny i wewnętrzny. W wymiarze zewnętrznym oznaczało chodzenie za Jezusem podczas jego wędrówek po Palestynie, natomiast w wymiarze wewnętrznym oznaczało nowe ukierunkowanie życia, w którym punktami odniesienia nie były już interesy, zawód, własna wola, lecz całkowite zdanie się na wolę Drugiego. Bycie do Jego dyspozycji stało się racją życia. Dzięki temu staje się widoczna istota naśladowania - jest to wewnętrzna przemiana życia. Wymaga otwarcia się, a nie uznawania własnej samorealizacji za główną rację życia. Wymaga to dobrowolnego oddania się drugiemu - dla prawdy, dla miłości, dla Boga, który w Jezusie Chrystusie wskazuje drogę. To podstawowa decyzja, by przestać uważać zysk i zarobek, karierę i sukces za ostateczny cel życia, tylko uznać za autentyczne kryteria prawdę i miłość. Jest to wybór między życiem tylko dla siebie a oddaniem siebie - dla większej sprawy. Miłość i prawda nie są wartościami

\footnotetext{
$35 \quad$ B. Ferdek, Nasza Siostra..., dz. cyt., s. 24.

Benedykt XVI, Homilia wygłoszona podczas Mszy św. Kanonizacyjnej, „L'Oss Rom" (PL), 1(2010), s. 16.

37 Por. „Zapuśćcie [w Nim] korzenie i na Nim dalej się budujcie, i umacniajcie się w wierze, jak was nauczono, pełni wdzięczności” (Kol 2,7).

38 Benedykt XVI, Orędzie na XXVI Światowy Dzień Młodzieży, „L'Oss Rom”(PL), 10(2010), s. 6.
} 
abstrakcyjnymi, ponieważ Jezus jest ich personifikacją. Podążać za Nim, to oddać się służbie prawdzie i miłości ${ }^{39}$.

Naśladowanie Chrystusa nie polega jedynie na słuchaniu nauki i na posłusznym przyjmowaniu przykazań. Oznacza ono coś bardziej radykalnego: przylgnięcie do osoby samego Jezusa, uczestnictwo w Jego życiu i przeznaczeniu, udział w Jego dobrowolnym i pełnym miłości posłuszeństwie woli Ojca. Naśladując przez wiarę Tego, Który jest Mądrością wcieloną, uczeń Jezusa staje się naprawdę uczniem Boga ${ }^{40}$.

Nie należy bać się powierzać życia Chrystusowi, bo On wie, co kryje się w sercach i nigdy nie zawodzi ludzkich oczekiwań ${ }^{41}$.

\section{Wiara i rozum}

Ludzie w swoim życiu często mają trudności w doprowadzeniu do pogodzenia nauki z wiarą. Pytają: $\mathrm{w}$ jaki sposób objawienie biblijne i teorie naukowe mogą spotkać się w poszukiwaniu prawdy. Często sądzą, że nauka i wiara są sobie wrogie; że nauka i technika są tym samym; że logika matematyczna odkryła wszystko, a świat jest dziełem przypadku. Zwłaszcza podczas studiów, nie zawsze łatwo jest sprowadzić argumenty do Bożego planu, wpisanego w naturę i w dzieje człowieka. I tak czasami wiara staje się chwiejna albo zostaje sprowadzona do zwykłego aktu uczuciowego.

Aby rozwiać wątpliwości związane $\mathrm{z}$ wiarą i rozumem Benedykt XVI wyjaśniał: „Albo Bóg jest, albo Boga nie ma: są tylko dwie możliwości. Albo postawimy na rozum, Rozum stwórczy, który dał początek wszystkiemu, albo na irracjonalizm, według którego wszystko, co istnieje, miałoby być przypadkowe" ${ }^{42}$. Wyraźnie kieruje myśli w stronę pożytku płynącego ze znajomości matematyki i nauk przyrodniczych: „Bóg zostawił nam dwie księgi - księgę Biblii napisaną językiem codziennym i księgę natury napisaną językiem matematyki” i dlatego „matematyka, genialny abstrakcyjny wymysł ludzkiego rozumu okazuje się

$39 \quad$ Benedykt XVI, Pan puka do bram świata. Msza św. w Niedzielę Palmowa- XII Światowy Dzień Młodzieży, „L'Oss Rom” (PL), 5(2007), s. 17.

40

41

VS 19.

Benedykt XVI, Kościót i społeczeństwo licza na młodzież. Przemówienie do zebranych przed katedra, „L'Oss Rom” (PL), 6(2007), s. 8.

2 Benedykt XVI, Dawajcie świadectwo o Bogu wświecie wspótczesnym. Rozmowa z mtodzieża Rzymu i Lacjum na placu św. Piotra, „L'Oss Rom” (PL), 6-7(2006), s. 51. 
przydatna do poznania natury i do wykorzystania jej, by nam służyła: (...) matematyka jest językiem Stwórcy: tak napisał księgę świata" ${ }^{43}$. W książce Jezus z Nazaretu Benedykt napisał:

Świat ukazuje się jako rzeczywistość rozumna: wywodzi się od wiekuistego Rozumu i tylko ten stwórczy Rozum stanowi rzeczywistą potęgę panującą nad światem i w świecie. Jedynie wiara w jednego Boga naprawdę wyzwala i „racjonalizuje” świat ${ }^{44}$.

W drugiej z kolei encyklice Spe salvi odwołuje się do powiązania nauk przyrodniczych z duchowością: są więc tacy ludzie - zauważa Benedykt XVI - „którzy uważają, że człowiek zostanie zbawiony przez naukę”. Oczywiście, „mając takie oczekiwania, zbyt wiele wymaga się od nauki; tego rodzaju nadzieja jest zwodnicza". Nie oznacza to jednak deprecjonowania tej dziedziny ludzkiej aktywności, a jedynie znalezienie dla niej właściwego miejsca w całości chrześcijańskiej wizji świata: „Nauka może wiele wnieść w proces humanizacji świata i ludzkości. Może jednak również zniszczyć człowieka i świat, jeśli nie jest ukierunkowana przez siły, które są poza nią"

Te dwa wymiary, wiara i rozum, nie mogą być od siebie oddzielane ani też sobie przeciwstawiane, lecz powinny zawsze iść razem. Wiara i rozum, jak napisał Augustyn, są „dwoma siłami, które prowadzą do poznania"46. Wierzący pragnie lepszego poznania Tego, w którym złożył swoją wiarę i lepszego zrozumienia tego, co On objawił; głębsze poznanie będzie domagać się z kolei większej wiary, coraz bardziej przenikniętej miłością: „wierzę, aby rozumieć, i rozumiem, aby głębiej wierzyć" $"$.

Harmonia między wiarą a rozumem oznacza przede wszystkim to, że Bóg nie jest daleki: nie jest daleko od naszego rozumu i od naszego życia; jest blisko każdego człowieka, blisko naszego serca oraz blisko naszego rozumu. Obecność Boga w człowieku jest bardzo głęboka i równocześnie tajemnicza, można ją jednak rozpoznać i odkryć w całej głębi.

Dialog wiary i rozumu prowadzony szczerze i konsekwentnie pozwala dostrzec racjonalność wiary w Boga - nie jakiegokolwiek boga,

43 Tamże, s. 50.

44 J. Ratzinger - Benedykt XVI, Jezus z Nazaretu. Od chrztu w Jordanie do Przemienienia (cz.1), Kraków 2011, s. 159.

45 http://www.tillit.pl/, A. Siemieniewski, Pochwała ludzkiego rozumu: od Jana Pawta II do Benedykta XVI, dnia 05.06.2011.

46 Św. Augustyn, Przeciw akademikom, III, 20, 43.

$47 \quad$ KKK 158. 
lecz Boga objawiającego się w Jezusie Chrystusie, bo tylko w Nim spełniają się wszystkie prawdziwe pragnienia człowieka ${ }^{48}$.

Wiara dopełnia rozum i go doskonali, a rozum, oświecony przez wiarę, znajduje moc, by wznieść się do poznania Boga i rzeczywistości duchowych. Wiara i rozum nie tylko nie mogą się nigdy z sobą kłócić, ale się wzajemnie wspomagają, ponieważ prawy sposób myślenia wykazuje podstawy wiary i umysł jej światłem oświecony oddaje się wiedzy o rzeczach Boskich; wiara zaś chroni i strzeże umysł przed błędami oraz wyposaża go wielorakim poznaniem.

\section{Kościół jako wspólnota wiary}

Wiara Kościoła jest tym, czego Bóg szuka w nas i co daje także odpuszczenie grzechów. Wyznawać tę samą wspólną wiarę. Możemy, musimy żyć tą wiarą, każdy na własny niepowtarzalny sposób, ale zawsze ze świadomością, że ta wiara nas poprzedza. Musimy też przekazywać tę wspólną wiarę wszystkim innym ${ }^{49}$.

Wiara nie jest aktem wyizolowanym. Wierzący otrzymał wiarę od innych, dlatego powinien ją przekazywać innym. Miłość do Jezusa i ludzi skłania do mówienia światu o wierze. Każdy wierzący jest jakby ogniwem w wielkim łańcuchu wierzących. Nie mogę wierzyć, jeśli nie będzie mnie prowadziła wiara innych, a przez moją wiarę przyczyniam się do prowadzenia wiary innych ${ }^{50}$.

Wiara jest aktem wspólnotowym, wyznaniem wiary Kościoła „wierzymy" "51. Kościół wierzy, a ja wierzę w jego wnętrzu, jako jego żywy kamień. Wyznanie „,wierzę” - podkreśla indywidualny wymiar wiary, która zawsze jest decyzją, aktem wolnego człowieka. Jednocześnie prawdą jest i to, że „nikt nie może wierzyć sam, tak jak nikt nie może żyć sam"52. Obie formy są prawdziwe i potrzebne. Naucza o tym Sobór Watykański II: „podobało się Bogu uświęcać i zbawiać ludzi nie pojedynczo, z wykluczeniem wszelkiej wzajemnej między nimi więzi,

Benedykt XVI, Radość płynaca z wiary i wychowanie nowych pokoleń. Do uczestników kongresu diecezji Rzymu, „L'Oss Rom” (PL), 12(2006), s. 15.

http://www.opoka.org.pl/Benedykt XVI, Rozważanie Papieża na rozpoczęcie I Kongregacji Generalnej Synodu Biskupów. Wspótpraca z Bogiem, który jest $z$ nami, dnia 05.06.2011.

KKK 166.

Benedykt XVI, Radość ptynaca z wiary..., dz. cyt., s. 13. 
lecz uczynić z nich lud, który by Go poznawał w prawdzie i zbożnie Mu służył"53.

Osobista wiara człowieka w Chrystusa, zrodzona z dialogu z Nim, jest złączona z wiarą Kościoła, w którym człowiek wiarę przyjmuje, wyraża, przeżywa, świadczy o niej i przekazuje ją we wspólnocie wierzących ${ }^{54}$. Kościół istnieje więc nie dla siebie, lecz dla ludzkości. Istnieje po to, by świat stawał się miejscem obecności Boga, miejscem przymierza Boga z ludźmi ${ }^{55}$. Chrystus żyje w Kościele i jest tajemnicą Chrystusa żyjącego i działającego pośród nas, jak mówi św. Paweł: „(...) Chrystus pośród was - nadzieja chwały” (Kol 1, 27), a także „Wy (...) jesteście Ciałem Chrystusa i poszczególnymi członkami” (1 Kor 12, 27). Poznanie Boga jest zaś drogą, którą Kościół ma ukazywać oraz proponować wspólne nią pielgrzymowanie.

Każdy powinien czuć się ,żywą cząstką” Kościoła, włączając się w dzieło ewangelizacji, bez obaw, w duchu szczerej zgody z braćmi w wierze i w jedności z pasterzami, wyzbywając się skłonności do indywidualizmu, także w życiu wiarą, aby w pełni cieszyć się tym ze wspólnego tworzenia wielkiej mozaiki Chrystusowego Kościoła ${ }^{56}$.

Człowiek wspierany jest przez wiarę Kościoła, aby mógł stać się wierzącym; jeżeli żaden człowiek nie jest samotną wyspą, tym bardziej nie jest nią chrześcijanin, który odkrywa w Kościele piękno wiary, podzielanej i świadczonej wspólnie z innymi w braterstwie i służbie miłości ${ }^{57}$.

Kto kocha Chrystusa, z taką samą pasją powinien kochać też Kościół, gdyż to on uczy człowieka żyć z Bogiem, pod Jego spojrzeniem i we wspólnocie z Nim${ }^{58}$.

Pomocą na drodze do Pana Boga jest Kościół, czyli wspólnota ludzi wierzących i ochrzczonych, którzy w relacji do Boga nie kierują się intuicją, lecz z całym zaufaniem przyjmują Boże Objawienie i strzegą go. Kościół daje pewność, że człowiek w drodze do Boga nie pobłądzi. Bóg ustanawiając Kościół, jako narzędzie, posługuje się nim

\footnotetext{
$53 \quad$ KK 9.

A. Zuberbier (red.), Stownik Teologiczny, s. 632.

J. Ratzinger, Pielgrzymująca wspólnota wiary. Kościót jako komunia, Kraków 2003, s. 264.

Benedykt XVI, Odważnie dokonujcie wyborów na całe życie i badźcie im wierni. Spotkanie z młodzieża, „L'Oss Rom” (PL), 7(2010), s. 36.

57 http://www.opoka.org.pl/, Benedykt XVI, Musimy wcią̇ na nowo odkrywać sens życia. Rozważanie przed modlitwa „Aniot Pański” Castel Gandolfo, dnia 31.05.2011.
} 
w prowadzeniu człowieka do siebie. Bóg uczynił z Kościoła miejsce spotkania człowieka ze sobą.

Naturalnym środowiskiem wiary jest Kościół i przestrzega, by nie dać się zwieść tym, którzy chcą przeciwstawić Chrystusa Kościołowi. Za tym przeciwstawianiem stoi fakt, że dla wielu współczesnych ludzi Kościół jawi się jako główna przeszkoda w wierze. Tymczasem „Kościół najbardziej jest nie tam, gdzie się organizuje, reformuje, rządzi, tylko w tych, którzy po prostu wierzą i w nim przyjmują dar wiary stający się dla nich życiem"59. Kościół jest więc miejscem przyjmowania daru wiary. Odrzucając Kościół odrzuca się jeden z elementów wiary, jakim jest posłuszeństwo Temu, z którym chcę związać swoje życie.

Chrystus rodzi się w Kościele, gdy na wzór Maryi przyjmowane są słowa powiedziane od Pana, albowiem: „Wiara rodzi się z tego, co się słyszy, tym zaś, co się słyszy, jest słowo Chrystusa" (Rz 10, 17). Od samego początku Kościół jest sługą tego Słowa Chrystusa, z którego rodzi się wiara, a jego Urząd Nauczycielski, tego Słowa święcie strzeże i wiernie wykłada, nauczając jedynie tego, co zostało przekazane ${ }^{60}$. Przeciwstawianie więc Chrystusa Kościołowi oznacza odcięcie od środowiska wiary. A poza Kościołem słowo Chrystusa jest interpretowane na wiele wzajemnie wykluczających się sposobów.

Osobista wiara w Chrystusa, zrodzona z dialogu z Nim, jest złączona $\mathrm{z}$ wiarą Kościoła. Przez chrzest jesteśmy członkami wielkiej rodziny i to wiara wyznawana przez Kościół daje pewność naszej wierze osobistej. Credo wyznawane podczas niedzielnej Eucharystii chroni nas przed niebezpieczeństwem wiary w innego Boga niż Ten, którego objawił nam Jezus ${ }^{61}$. Osobiste zaangażowanie $\mathrm{w}$ wierze musi zawsze opierać się na mocnym fundamencie Kościoła. W przeciwnym wypadku wierze grozi zejście na bezdroża ${ }^{62}$. A zatem tylko i wyłącznie w Kościele i za jego pośrednictwem możemy spotkać Chrystusa i dokonywać weryfikacji swojej wiary ${ }^{63}$. Człowiek wierzący, który pozwala się ukształtować i prowadzić przez wiarę Kościoła, powinien - bez względu na to, jakie by nie były jego słabości i trudności - być oknem otwartym na światło Boga żywego, a jeśli naprawdę wierzy, to jest nim istotnie ${ }^{64}$.

\footnotetext{
$59 \quad$ J. Ratzinger, Wprowadzenie w chrześcijaństwo..., dz. cyt., s. 362.

$60 \quad$ KO 10.

Benedykt XVI, Orędzie na XXVI Światowy Dzień Młodzieży, „L'Oss Rom”(PL), 10(2010), s. 4

E. Ozorowski, Kościót. Zarys eklezjologii katolickiej, Wrocław 2005, s. 19.

Benedykt XVI, Otwórzcie szeroko wasze serca Chrystusowi, Powitanie uczestników Światowego Dnia Młodzieży, „L’Oss Rom” (PL), 10(2005), s. 13-14. 
Wielu nie jest w stanie utożsamić się z całym nauczaniem Kościoła, zrozumieć je i przyjąć. Trzeba obudzić w człowieku pragnienie, żeby chciał wierzyć z Kościołem, nawet, jeśli nie przyjął jeszcze wielu elementów tej wiary, by przylgnął do niego nawet, jeśli w pełni go nie pojął, ufał i miał udział w wierze Kościoła. Jest to ciągła pielgrzymka życia: dążyć myślą, uczuciem, całym życiem do komunii wiary ${ }^{65}$. Należy umiłować Kościół i postępować według jego nauki, ponieważ otrzymał od swego założyciela misje ukazywania ludziom drogi do prawdziwego szczęścia. Kościół pozwala również zbliżyć się do skarbu o tak wielkiej wartości i uczy właściwie oceniać jego bogactwo ${ }^{66}$. Kościół daje Jezusa Chrystusa. Otwiera drzwi do Boga i przez to daje ludziom to, czego najbardziej oczekują i to, co może im najskuteczniej pomóc ${ }^{67}$.

\section{Wiara, nadzieja i miłość}

W encyklice Deus Caritas Est, Benedykt XVI pisze, że wiara, nadzieja i miłość są nierozdzielne. Te cnoty teologalne wzajemnie się warunkują, umacniają, dopełniają i na siebie oddziałują.

Cnoty teologalne kształtuja, pobudzają i charakteryzują działanie moralne chrześcijanina. Kształtują one i ożywiają wszystkie cnoty moralne. Są wszczepione przez Boga w dusze wiernych, by uzdolnić ich do działania jako dzieci Boże i do zasługiwania na życie wieczne. Stanowią one rękojmię obecności i działania Ducha Świętego we władzach człowieka ${ }^{68}$.

Wierzymy w Boga, w Boga będącego początkiem i celem ludzkiego życia. W Boga, który obcuje z nami, ludźmi, od którego pochodzimy i który jest naszą przyszłością. W tym sensie wiara jest zawsze również nadzieją, pewnością, że przed nami jest przyszłość, a nie próżnia. Wiara jest także miłością, gdyż miłość Boża chce się nam „udzielić”. A więc, wierzymy po prostu w Boga, a to oznacza również nadzieję i miłośćc9.

65 Benedykt XVI, Z wielka miłościa do Chrystusa i Kościoła. Na zakończenie spotkania $z$ duchowieństwem diecezji rzymskiej, „L'Oss Rom” (PL), 7-8(2005), s. 15.

66 Benedykt XVI, Twoje stowo jest lampa dla moich kroków i świattem na mojej ścieżce. Orędzie Ojca Świętego na XXI Światowy Dzień Młodzieży 2006 r., „L'Oss Rom" (PL), 4(2006) s.6.

67 Benedykt XVI, P. Seewald, Świattość świata. Papiė̇, Kościót i znaki czasu, Kraków 2011, s. 182.

KKK 1813.

69 http://www.kuria.lomza.pl, Benedykt XVI, Nasza podstawowa decyzja-wierzymy $w$ Boga. Homilia Ojca Świętego wygłoszona w Ratyzbonie podczas podróży apostolskiej do Bawarii, dnia 05.06.2011. 
Być chrześcijaninem to pielgrzymować w wierze, nadziei i miłości. Benedykt XVI podkreśla, że prawdziwa miłość jest ewidentnie czymś bardzo dobrym. Bez niej trudno byłoby stwierdzić, że „warto żyć”. Miłość satysfakcjonuje nasze najgłębsze potrzeby, a kiedy kochamy, możemy być w pełni sobą. Przyznaje, że miłość nadaje zupełnie nowy smak i nowy sens życiu człowieka. „Kogo dotyka miłość, ten zaczyna mieć intuicję, czym właściwie jest «życie»"70 - czytamy w encyklice. Miłość należy więc do struktury wiary i dzięki temu „wiara chrześcijańska nie jest ideą, tylko życiem"71.

Naprawdę żyć oznacza poddać się przemianie wewnętrznej, otworzyć się na moc Bożej miłości ${ }^{72}$, bo „każde osobiste spotkanie z Jezusem jest doświadczeniem nieprzepartej miłości" ${ }^{\prime 7}$.

Papież Benedykt również zaznacza, że zwycięstwo, które rodzi się z wiary, jest zwycięstwem miłości „Któż zwycięża świat, jeśli nie ten, kto wierzy, że Jezus jest Synem Bożym” ( $1 \mathrm{~J} 5,5)$. Wielu chrześcijan jest żywym świadectwem mocy wiary, objawiającej się w miłości - są oni budowniczymi pokoju, orędownikami sprawiedliwości, propagatorami bardziej ludzkiego świata według Boga, angażującymi się w rozmaitych dziedzinach życia społecznego, pracującymi dla dobra wszystkich. Miłość wynikająca z wiary powinna prowadzić do konkretnego świadectwa, które przejawia się w czynach i słowach - Chrystus nie jest dobrem tylko dla nas samych, ale najcenniejszym dobrem, jakim trzeba dzielić się z innymi ${ }^{74}$. Miłość do bliźniego jest więc pięknym odzwierciedleniem miłości do Boga ${ }^{75}$.

Jezus wskazuje na miłość, jako najważniejsze i największe bogactwo. Słowo miłość może być jednak różnie interpretowane i mieć rozmaite znaczenia, dlatego potrzebny jest nam Nauczyciel - Chrystus, który wskazuje najgłębszy i autentyczny sens, który prowadzi do źródła miłości i życia. Miłość jest imieniem Boga. Jak pisał Apostoł Jan „Bóg

\footnotetext{
$70 \quad$ Benedykt XVI, Spe Salvi..., dz. cyt., s. 37.

71 J. Ratzinger, Wprowadzenie w chrześcijaństwo, dz. cyt., s. 99.

72 Benedykt XVI, Otwierajcie serca na dary Ducha Świętego. Czuwanie młodzieży na hipodromie w Randwick, „L'Oss Rom” (PL), 9(2008), s. 28.

73 Benedykt XVI, Badźcie serdecznymi przyjaciótmi Jezusa. Spotkanie z młodzieża $w$ porcie, „L'Oss Rom” (PL), 6(2010), s. 13.

74 Benedykt XVI, Orędzie na XXVIŚwiatowy Dzień Młodzieży, „L'Oss Rom”(PL), 10(2010), s. 8.

$75 \quad$ A. Proniewski, Doświadczenie wiary w życiu..., dz. cyt., s. 100.
} 
jest miłością (...) nie my umiłowaliśmy Boga, ale On sam nas umiłował i posłał Syna swojego"76.

Jesteśmy przeznaczeni do tego, by poznać Boga miłości, który jest Ojcem, Synem i Duchem Świętym i odnaleźć ostateczne wypełnienie w tej Boskiej miłości, która nie zna początku ani końca ${ }^{77}$. Zostaliśmy stworzeni po to, by być kochani, ale także po to, by dawać miłość. Ma ona być najtrwalszą rzeczą w życiu każdej osoby. W miłości chrześcijańskiej miłość Boga i miłość bliźniego są nierozdzielnie złączone, a miłość bliźniego oznacza bardzo konkretne zaangażowanie ${ }^{78}$.

Nadzieja stanowi kluczowe znaczenie w życiu każdego człowieka, przede wszystkim w czasach współczesnych. „Wszyscy odczuwamy potrzebę nadziei, ale nie jakiejkolwiek nadziei, lecz nadziei solidnej i niezawodnej [...]"79. Podkreśla, że młodość jest szczególnym czasem nadziei, gdyż ma w stosunku do przyszłości różne oczekiwania. W młodości człowiek ma ideały, marzenia i plany, młodość to czas dojrzewania wyborów decydujących o reszcie życia. Jest to również czas poszukiwania nadziei w chwilach trudności kryzysów, porażek ${ }^{80}$.

Tą nadzieją może być tylko Bóg, który ogarnia Wszechświat i który może zaproponować i dać to, czego nikt z nas nie mógłby osiągnąć. Bez Boga, poza Bogiem i związaną z Nim nadzieją nie ma nie tylko nadziei i wiary, ale również nie ma szczęścia, sprawiedliwości i życia w prawdzie. „Nadzieją, która nigdy nie zawodzi jest Jezus Chrystus”"1.

Kto nie zna Boga, chociaż miałby wielorakie nadzieje, w gruncie rzeczy nie ma nadziei, wielkiej nadziei, która podtrzymuje całe życie. Prawdziwą, wielką nadzieją człowieka, która przetrwa wszelkie zawody, może być tylko Bóg, który nas umiłował i wciąż nas miłuje „aż do końca”, do ostatecznego „wykonało się"82.

76

Benedykt XVI, Odważnie dokonujcie wyborów na całe życie i badźcie im wierni. Spotkanie z młodzieża, „L'Oss Rom” (PL), 7(2010), s. 35.

77

Benedykt XVI, Zostaliśmy stworzeni, by być kochani i obdarzać mitością. Spotkanie z mtodzieża przed katedra westminsterska, „L'Oss Rom” (PL), 11(2010) s. 34 .

Benedykt XVI, Radość ptynaca z wiary i wychowanie nowych pokoleń. Do uczestników kongresu diecezji Rzymu, „L'Oss Rom”(PL), 12(2006) s. 15.

Benedykt XVI, Orędzie na XXIV Światowy Dzień Młodzieży, „L'Oss Rom”(PL), 4(2009) s. 4.

80 Tamże.

81 BenedyktXVI, Wyjesteście uczniami Chrystusaw dzisiejszym świecie. Spotkanie $z$ młodzieża w Seminarium św. Józefa, „L’Oss Rom” (PL), 6(2008) s. 25.
Wiara 
Nadzieja to nie jedynie ideał czy uczucie, lecz żywa osoba: Jezus Chrystus, Syn Boży. „Złożyliśmy nadzieję w Bogu Żywym”. „Żywy Bóg” to Chrystus zmartwychwstały i obecny w świecie. To on jest żywą nadzieją. Chrystus wzywa każdego człowieka do udziału w Jego życiu wiecznym. Nie należy się niczego lękać, bo On jest z każdą osobą, On jest teraźniejszością i przyszłością. Nadzieja chrześcijanina to zatem tyle, co pragnąć ,,jako naszego szczęścia Królestwa Niebieskiego i życia wiecznego, pokładając ufność w obietnicach Chrystusa i opierając się nie na naszych siłach, ale na pomocy łaski Ducha Świętego"83.

\section{Wieczność - jako ostateczny cel wiary}

Człowiek stworzony jest do rzeczy wielkich, do nieskończoności ${ }^{84}$. Pytanie o przyszłość, jaka ostatecznie czeka każdego, nadaje życiu pełny sens, ponieważ wytycza życiowy plan nie ku horyzontom ograniczonym i nietrwałym, lecz szerokim i głębokim, które skłaniają do umiłowania świata, przez samego Boga tak bardzo umiłowanego, do starania się o jego rozwój, ale zawsze w wolności i z radością, które rodzą się z wiary i nadziei. Te horyzonty pomagają nie absolutyzować rzeczywistości ziemskiej, dając poczucie, że Bóg przygotowuje perspektywę większą, by móc powtórzyć za św. Augustynem: „Pożądamy razem ojczyzny niebieskiej, tęsknimy za ojczyzną niebieską, czujemy się pielgrzymami na tym świecie" ${ }^{\natural 5}$.

Człowiek w swoich projektach życia nie może zapominać o tej perspektywie, jaką jest wieczność, do której każdy jest powołany. Bóg stworzył nas, byśmy byli z Nim na zawsze. To pomaga nadać pełen sens wyborom i jakość życiu ${ }^{86}$. Wiara w Boga prowadzi nas do zwrócenia się do Niego samego, jako naszego pierwszego początku i ostatecznego celu ${ }^{87}$.

Młodość jest czasem przygotowującym przyszłość, bo ,jutro” w dużej mierze zależy od tego, jak przeżyjemy „dzisiaj”. Nie można pozwolić, aby życie przeminęło daremnie, nie można go zmarnować, należy

\section{KKK 1817.}

Benedykt XVI, Orędzie na XXVI Światowy Dzień Młodzieży, „L'Oss Rom”(PL), 10(2010), s. 4.

Św. Augustyn, Komentarz do Ewangelii św. Jana, Homilia 35, 9.

Tamże.

KKK 229. 
przeżyć je z radością, z entuzjazmem, przede wszystkim z poczuciem odpowiedzialności ${ }^{88}$.

Wiele osób odrzuca dziś wiarę. Życie wieczne nie jest rzeczą przez nich pożądaną. Wybierają życie doczesne, jako to, o które jedynie warto walczyć. Wiara w życie wieczne jest dla nich przeszkodą, sprostanie wymaganiom jest utrudnieniem, bardziej wyrokiem niż darem. Natomiast chciałoby się odsunąć śmierć jak najdalej. Ale żyć zawsze, bez końca - to w sumie może być tylko nudne i ostatecznie nie do zniesienia. Mimo to pytanie o ,życie wieczne” pojawia się w szczególnie bolesnych chwilach życia, w chwili śmierci bliskiej osoby czy w przypadku jakiegoś niepowodzenia.

Najlepiej wyjaśnia, czym jest to „życie wieczne”, Jezus Chrystus, kiedy zwrócony do swoich uczniów, potwierdza: „Znowu jednak was zobaczę, i rozraduje się serce wasze, a radości waszej nikt wam nie zdoła odebrać" (J 16, 22). Są to słowa, które wskazują na propozycję ogarniętą szczęściem bez końca i radością bycia napełnionym Bożą miłością na zawsze ${ }^{89}$.

Słowa kluczowe: wiara, Benedykt XVI, łaska, Kościół.

88 Benedykt XVI, Jesteście młodym obliczem Kościoła i ludzkości. Spotkanie z młodzieża na stadionie miejskim Pacaembu, „L'Oss Rom” (PL), 7-8(2007), s. 19.

89 Benedykt XVI, Orędzie na XXV Światowy Dzień Młodzieży, „L'Oss Rom” (PL), 5(2010), s. 5-6. 